\title{
LEADERSHIP IN THE SUCCESSION PROCESS: THE CASE OF A FAMILY BUSINESS ${ }^{1}$ FROM MEXICO ${ }^{1}$
}

\author{
María Olivia Palafox Soto \\ Technological Institute of Sonora \\ Department of Administrative Sciences \\ Cd. Obregón Sonora, México \\ palafoxsotom@gmail.com
}

\author{
Sergio Ochoa Jiménez ${ }^{2}$ \\ Technological Institute of Sonora \\ Department of Administrative Sciences \\ Cd. Obregón Sonora, México \\ sochoa@itson.edu.mx
}

\author{
Carlos Armando Jacobo Hernández \\ Technological Institute of Sonora \\ Department of Administrative Sciences \\ Cd. Obregón Sonora, México \\ cjacobo@itson.edu.mx \\ Reception Date: 04/02/2019 - Approval Date: 05/31/2019
}

\begin{abstract}
Family businesses are of great importance because they have generated new jobs over the years, allowing them to be the object of study in various investigations; despite this, no emphasis has been placed on case studies that highlight both leadership and the decisive process in this type of organizations, known as succession. As a result, concern was generated to study a company that has gone through this process, where the main purpose is to show the ability to solve problems, challenges and how to cope with succession, in addition to knowing whether leadership is a key factor in it, deepening it to a greater extent in a case study, with semi-structured interview guides. After analyzing and interpreting what the informants mention, it is obtained as a result that leadership was a fundamental piece in this process, with an autocratic leadership that was exercised by the founder of the company. Currently, the new owner has used different types of leaderships depending on the situation, called situational. It is recommended to continue with that leadership style that characterizes him and to continue to be successful as a recognized family business.
\end{abstract}

KEY WORDS: Leadership; Succession; Family; Business.

\footnotetext{
1 Publication financed with resources from the Program to strengthen educational quality (Programa Fortalecimiento de la Calidad Educativa - PFCE-2018) of the Ministry of Public Education (Secretaría de Educación Pública - SEP) of Mexico.

${ }^{2}$ Correspondence Author.

"Visión de Futuro" Año 16, Volumen N²3 N², Julio - Diciembre 2019 - Pág. 90 - 101

URL de la Revista: http://visiondefuturo.fce.unam.edu.ar/index.php/visiondefuturo/index

URL del Documento: http://visiondefuturo.fce.unam.edu.ar/index.php/visiondefuturo/issue/view/16

ISSN 1668 - 8708 - Versión en Línea

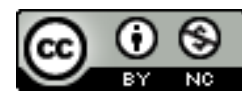




\section{INTRODUCTION}

Family businesses (hereafter referred to as FB) have been the oldest form of organization that exists, they are the type of organization with greater presence around the world, due to the important relationship they have with the economy and society (Velázquez et al, 2011); therefore, there is a clear trend in having a greater number of such companies (Quijada and Ávila, 2016).

One of their main processes is succession, which is a crucial moment that according to Araya (2012) is inevitable for their future since it is characterized by seeking permanence from generation to generation. When deciding who will be the successor (San Martin and Durán, 2016), without a doubt, is the most relevant process in any type of company (Tapiés, 2010). For this to be successful, it is important to exert a type of leadership that has the essential quality of making things work by promoting the example and leading the organization to achieve what is proposed (Gonzalo, 2006).

Several researches show that leadership is one of the most analyzed elements in FB, due to the great commitment, time and effort made by its collaborators (Vallejo, 2007); which allows to achieve progress, knowledge and motivation to resolve any situation that arises in a particular way, with confidence, security and stability at the end of the succession (Lozano and Urbano, 2017). This will allow to achieve a better planning for the future, letting them to subsist within the competitive market (Virick \& Greer, 2012).

Due to the importance of leadership within the succession process, to the degree of defining the survival and continuity of the FB and in view of the lack of knowledge of this in organizations, this study aims to identify the type of leadership applied during the succession process in a family business in northern Mexico, and thereby, to generate proposals or models for improvement to help it or others in their permanence. Conducting this type of research helps the FB to identify the type of leadership exercised; in addition, to determine which is the most convenient style that helps the company to guide, along the right path during the succession process; it is important to mention that an effective leadership helps to achieve the goals and objectives established (Ulloa et al, 2012).

In order to fulfill the research objective, a documentary search was carried out that was integrated into the state of the art, which forms the first part of this document. The second section consists of the method, describing in detail the way in which the interviews were conducted to the members of the company under study. Subsequently, the results focused mainly on the type of

"Visión de Futuro" Año 16, Volumen No 23 N², Julio - Diciembre 2019 - Pág. 90 - 101

URL de la Revista: http://visiondefuturo.fce.unam.edu.ar/index.php/visiondefuturo/index

URL del Documento: http://visiondefuturo.fce.unam.edu.ar/index.php/visiondefuturo/issue/view/16

ISSN 1668 - 8708 - Versión en Línea

E-mail: revistacientifica@fce.unam.edu.ar 
leadership and other factors related to the succession process are described. Finally, the main conclusions derived from this research are briefly included.

\section{DEVELOPMENT}

FB are systems made up by certain similar aspects that unite them, such as their relationships, conflicts, organizational culture, business philosophy, among other variables (Sandoval and Guerrero, 2010); in addition, it is important to take into account some factors of this type of companies, such as the participation of the family, where its primary achievement is that of continuity and that its decision-making is carried out by members of the same family nucleus. Several authors agree that FB are related by the family ties and that the ownership of the organization belongs to the same family (Manzano and Ayala, 2002), seeking to offer the essential to each worker and achieve in them a professional and personal development, either ethical and affective, which will benefit the organization in all aspects, (Salazar, 2014).

The FB are those where their members belong to the same nucleus or family system, sharing the company and the property as a whole, in order to achieve the proposed objectives, always allowing the continuity of the same and maintaining the relationship between the elements of company, property and family (Tagiuri and Davis, 2012). Surviving the succession planning through these three elements or systems is a big challenge for them (Arenas and Rico, 2014). It establishes a set of relationships between the same employees, mainly by the family association within it, which in many situations could cause certain conflicts, but also benefits (Ochoa et al, 2015).

From long ago, FB have represented the basis of organization and economy. They are known as the direct antecedent of today's large and modern companies, always pursuing succession and permanence, and applying values to achieve success (Rendón, 2010); what allows them to do so is the antiquity they have in the market, the generations they have passed through, the context in which they are (urban, rural, modern or traditional) and the history of the company, as these are characteristics that have allowed them to get to know the family from its past to its present, and thus remain competent (Jiménez and Piña, 2011).

All the elements of $\mathrm{FB}$ are necessary to know in depth what a company of this type implies and to know what role or function the collaborators are developing within it. It is worth mentioning that they stand out for maintaining certain characteristics, such as working with the same rhythm

"Visión de Futuro" Año 16, Volumen No 23 N², Julio - Diciembre 2019 - Pág. 90 - 101

URL de la Revista: http://visiondefuturo.fce.unam.edu.ar/index.php/visiondefuturo/index

URL del Documento: http://visiondefuturo.fce.unam.edu.ar/index.php/visiondefuturo/issue/view/16

ISSN 1668 - 8708 - Versión en Línea

E-mail: revistacientifica@fce.unam.edu.ar 
as their predecessors, maintaining what they transmitted to them, such as knowledge, values and skills that taught them to continue developing effectively in the company (Lee, 2012).

\section{Leadership}

Leadership can be defined as a quality that must have a high command, making sure to promote the example and ensure that others act motivated to promote the transcendence of the organization, improving the commitment with the company and allowing them to last (Gonzalo, 2006), and being a good example to follow and managing to influence others in different ways. It is of great importance in all types of organization since good leadership contributes to a good orientation towards the established objectives of the company; on the contrary, not having a good leadership, the company may be affected when it meets its objectives and the guide, and not being able to get ahead with the succession process through which it is going (Van and Yukl, 2015).

Several authors have different opinions on leadership; however, it must be understood that a leader must be able to control their emotions, intelligence, skills and abilities to bring good to the organization, because the behaviors and characteristics that maintain influence the actions of their subordinates (Zarate and Matviuk, 2012). It must exert a positive influence on others, characterized by being realistic, skillful, daring, open-minded, close, innovative, creative, ethical, among other aspects that make him an example for others (Carrión, 2017), especially for being motivated, exercising power and authority before all, promoting change, teamwork, the performance of workers, and thus achieve satisfaction for the obtained goal, creating an optimal and harmonious working environment (Arteaga and Soraya, 2009).

It is stated by some authors that there are several types of leadership; however, others mention that there is only one leadership, and it is about that the leaders who choose different ways of working keeping the example for others. It can also be said that there are only three ways in which you can exercise leadership: the first of them is the charismatic, where it makes everyone work in a harmonious way and with enthusiasm; the traditional one where the leader is considered so by nature and by the position he holds; and finally the legitimate one who always follows the rules and procedures for his subordinates to do things in the same way (Figueroa, 2012), so the success of an organization depends on the way they applied their leadership (Goleman, 2013).

Broadening the horizons of the types, it is possible to mention the entrepreneurial type, which is the one that influences and directs the behavior of the workers; the autocratic, where the leader only gives orders; the democratic, where the leader takes the decisions together with his

"Visión de Futuro" Año 16, Volumen N²3 N², Julio - Diciembre 2019 - Pág. 90 - 101

URL de la Revista: http://visiondefuturo.fce.unam.edu.ar/index.php/visiondefuturo/index

URL del Documento: http://visiondefuturo.fce.unam.edu.ar/index.php/visiondefuturo/issue/view/16

ISSN 1668 - 8708 - Versión en Línea

E-mail: revistacientifica@fce.unam.edu.ar 
subordinates with the purpose of creating a better working environment (Soto, 2012); it also exists the laissez faire, that its meaning comes from the French and means let do, where the leader is liberal, and sometimes is very effective because sometimes you must let others do the activities without being aware of them; the paternalist, in which the leader offers incentives or rewards to those who perform their work correctly; the charismatic, where the leader is visionary and inspiring what makes the company give a positive image; as well as situational leadership, that its effectiveness is in the ability of the leader or leaders to respond in different ways to various situations or difficulties (Sánchez, 2000).

On the other hand, Blake and Mouton (1980) established other types of leadership based on a model called Managerial Grid, which consists of placing the concern of leaders in relation to how they feel, to realize that this model is a tool that can help situate the types of leadership that are applied in organizations, resulting in quite a few styles that are used in FB and those that are not.

The topic of leadership and FB have been approached with different points of view, such as knowing the style of leadership applied by senior managers in FB (Gonzalo, 2006), analyzing a type of leadership in FB and the effects it has (Vallejo, 2007; Vallejo, 2009), as well as knowing leadership in small family businesses (Bastar, 2006).

\section{Succession}

Succession is an issue of great importance within companies because it consists of achieving the permanence of the organization, when looking among family members who will assume the position of manager. This is a complex issue since there is uncertainty of the performance of the successor (Araya, 2012). It is distinguished by the change of powers, where there is the influence of the founders of the company, becoming an unavoidable aspect that at some point has to be carried out because the future depends of it.

It is worth mentioning that there are a series of factors or elements in the successor process that favor it and facilitate its execution: the good relationship, the attitude in the family, disposition, respect, freedom and autonomy (Araya, 2012); as well as the vision of the future and the ages of the relatives in the company since they are two elements of which the founder of the company takes into account to be able to transfer the company to another generation (González and Navas, 2017); moreover, the family harmony within and outside the organization, the trust among employees and senior management and between themselves, and above all the existing relations between the owner and the successor (Mariscal et al, 2016).

"Visión de Futuro" Año 16, Volumen N²3 N², Julio - Diciembre 2019 - Pág. 90 - 101

URL de la Revista: http://visiondefuturo.fce.unam.edu.ar/index.php/visiondefuturo/index

URL del Documento: http://visiondefuturo.fce.unam.edu.ar/index.php/visiondefuturo/issue/view/16

ISSN 1668 - 8708 - Versión en Línea

E-mail: revistacientifica@fce.unam.edu.ar 
Thus, studying succession is a subject of great importance due to the multiple authors who have investigated and take it as an object of study from different points of view (Andrade, 2002; Manzano and Ayala, 2002; Santamaría and Pico, 2015; Pantoja et al, 2016).

\section{Analysis of leadership in the succession process}

To maintain a good leadership in any difficulty is of great help because it solves circumstances that can be negative for the company, so it is necessary to learn to develop all the virtues and strengths necessary. It also has an even greater impact during the succession process, because the FB enters a critical state when leadership is not present in this process and it does not guarantee permanence and growth (Saldaña et al, 2016); therefore, having it, is a fundamental competitive advantage due to it allows to act in circumstances that may arise unexpectedly or not, such as the succession process where the same owner can guide his/her workers by being a good leader (Gil et al, 2011). Although the succession process is known as an adversity for some businessmen, for others it is an opportunity to leave the future of the company in the hands of others, hoping that it will be the most profitable possible for future generations.

\section{Methodology}

This research has a descriptive scope; it mainly seeks to specify the importance of the problem being addressed (Cazau, 2006). It is also qualitative in nature, which required in-depth work and analysis because it was a case study in which the variables, as well as the qualities and characteristics of an organization were examined (Ávila, 2006).

The initial part of the study consisted of a documentary search for scientific articles related to both theoretical and empirical study variables. Subsequently, the found articles were analyzed, selecting only those that annexed an instrument (interview guide or questionnaire) that would be taken as the basis for designing a definitive interview guide. A total of 33 articles were obtained, choosing two instruments related to similar studies about succession and leadership within FB by authors Rodríguez and Camacho (2010) and Manning (2013). The question guide was elaborated based on the previous articles, as shown in Table $\mathrm{N}^{\circ} 1$.

Table $\mathbf{N}^{\circ}$ 1. Interview Guide

1.- How have the succession processes been in the company?

2.- Who and how did they influence succession planning to choose the new leader of the company?

3.- What were the most difficult experiences or situations after the succession process took place?

4.- What kind of problems existed and how did the family members solve them during the succession process?

"Visión de Futuro" Año 16, Volumen No 23 No2, Julio - Diciembre 2019 - Pág. 90 - 101

URL de la Revista: http://visiondefuturo.fce.unam.edu.ar/index.php/visiondefuturo/index

URL del Documento: http://visiondefuturo.fce.unam.edu.ar/index.php/visiondefuturo/issue/view/16

ISSN 1668 - 8708 - Versión en Línea

E-mail: revistacientifica@fce.unam.edu.ar 
5. What forms and criteria of selection were used to determine the new leader in the family business and achieve a successful succession?

6.- In the next succession process, what would you like to see in the future as a family legacy?

7.- What are the main characteristics that the new leader must have in order to apply them in the company?

8.- Do you believe that the type of leadership you currently exercise in the organization is ideal for the company's objectives?

9.- How does your leadership style affect your employees?

10.- Which is the most representative characteristic that a leader must have in order to continue with the family legacy of the company?

Source: Own Elaboration, based in Rodriguez and Camacho (2010) and Manning (2013)

The above guide was the basis for conducting the interviews at the service company located in northern Mexico, which is made up primarily by the family nucleus. It has a total of 16 workers: three of them are in charge of the workers' food (dining room and cleaning), three are bakers, one is a kneader, two are in customer service (sales), and the rest are in production (elaboration and packaging of the product). Eight interviews were conducted with representatives of all the positions in the company.

Once all the interviews with the company's informants had been concluded, the electronic audio recordings previously made were transcribed into Word, and then processed using the program called Atlas.ti to integrate qualitative data. A document in Excel was elaborated in which all the repeated words in the interviews were analyzed, and the relationship between them was identified, to later group them and determine the most frequent ones.

Finally, we proceeded to make a grouping of words with the analysis previously performed, resulting in five dimensions: leadership, succession, family, values and company. To conclude, each dimension was interpreted and the relationship that these dimensions have with the study variables and with the company in question was explained.

\section{Case Study}

The company in question had its beginnings more than 30 years ago, approximately in 1985; however, before establishing a business as such, its founder was previously dedicated to the production of cookies and sweet empanadas in her home, with the support of her family and some neighbors; it was not until 2006 that the opening of a formal business took place with products (empanadas) of different flavors.

The founder comes from a working family, she had 12 siblings and everyone knew that she was interested in cooking. At the beginning, she cooked pumpkin empanadas, but later she

"Visión de Futuro" Año 16, Volumen No 23 N², Julio - Diciembre 2019 - Pág. 90 - 101

URL de la Revista: http://visiondefuturo.fce.unam.edu.ar/index.php/visiondefuturo/index

URL del Documento: http://visiondefuturo.fce.unam.edu.ar/index.php/visiondefuturo/issue/view/16

ISSN 1668 - 8708 - Versión en Línea

E-mail: revistacientifica@fce.unam.edu.ar 
began to cooked more jams with the help of her children, such as dulce de leche, fig and guava cajeta; her recipes came from preparing various desserts and making modifications in the dough. Her sons and nephews were the ones who helped to sell the product through the streets of the village since her family always supported the business, although they had other aspirations.

As time went by, the business was formalized with the taxing authority with the help of an accountant; then, the workload increased, it was there that she needed the help of someone else to help her with the business, also because her health was deteriorating. At that moment, the founder decided to call her eldest son (current owner), so that he would be in charge of the business. His son lived in a nearby town with his wife and daughters. Over time, her son was in charge of the purchases and took control of the business administration, while her mother (founder) only supervised the production. By that time, the founder had acquired a piece of land in which she asked that the deeds were signed with the name of her eldest son, who would pay a part of the total cost of the land; it was there where a new place was built, which took seven years to be built thanks to its current owner.

The founder was proud of what her son had accomplished in the time he was helping her, she was confident she had made a good decision, and she wanted the tradition to remain a legacy for many years, and that is what her son has concretized. With the help of her family she has been able to carry on the business that she has worked so hard to achieve, despite the difficulties, she has managed to make it through.

Today, the company is widely recognized not only in the northern part of Mexico, but also in the United States and various parts of the world; tourists have come to visit only to try the empanadas in their different flavors. Upon arrival at the business, part of the family's identity can be visualized, such as the reed ornaments made by the owner himself, the town's motto at the entrance to the place and, above all, a photograph that keeps alive the image of its founder to remember that she is still present in a symbolic way with the gastronomic legacy that can be enjoyed.

\section{Results in relation to the studied variables}

Prior to the succession process, the family structure of the company was as can be seen in the figure $\mathrm{N}^{\circ} 1$, formed by the founder and her family, where she as leader and owner is who made each and every decision of the family business.

"Visión de Futuro" Año 16, Volumen No 23 No2, Julio - Diciembre 2019 - Pág. 90 - 101

URL de la Revista: http://visiondefuturo.fce.unam.edu.ar/index.php/visiondefuturo/index

URL del Documento: http://visiondefuturo.fce.unam.edu.ar/index.php/visiondefuturo/issue/view/16

ISSN 1668 - 8708 - Versión en Línea

E-mail: revistacientifica@fce.unam.edu.ar 


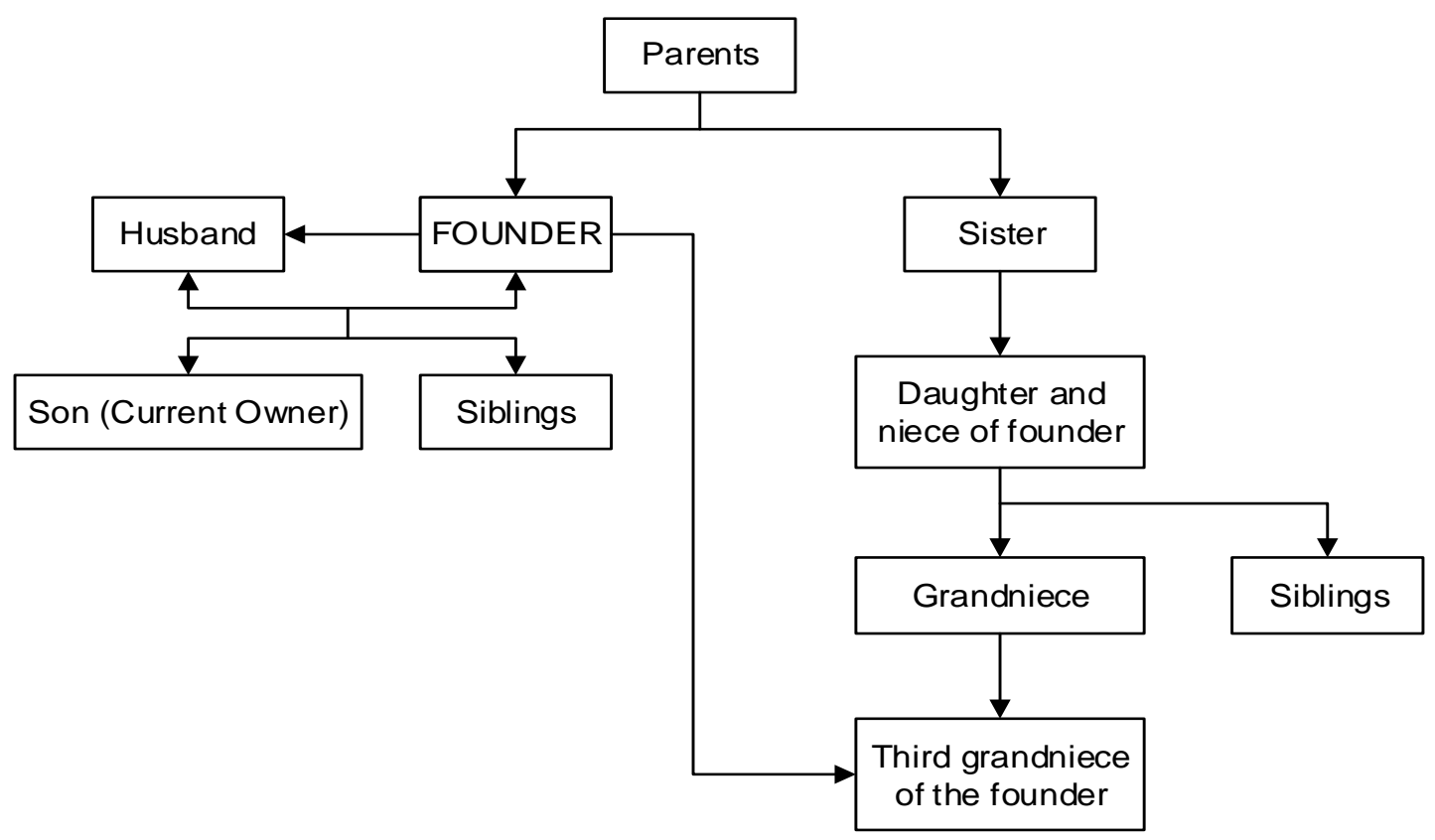

Figure $N^{\circ}$ 1. Family contribution with the founder of the company

Source: Own Elaboration

After the succession process, the company changed in the conformation of the family, as well as the organization chart, due to there were some family problems from that process, a sister of the current owner, created her own empanadas company thanks to everything she learned with her mother, today has its own workers.

Within the new hierarchical structure of the company, the successor is the one who directs, because for the founder it was the best option to be the best prepared of the family to take charge of the business; however, since there are certain differences, the sister is the one who works on her own in her company, as shown in Figure $N^{\circ} 2$.

"Visión de Futuro" Año 16, Volumen No 23 N², Julio - Diciembre 2019 - Pág. 90 - 101

URL de la Revista: http://visiondefuturo.fce.unam.edu.ar/index.php/visiondefuturo/index

URL del Documento: http://visiondefuturo.fce.unam.edu.ar/index.php/visiondefuturo/issue/view/16

ISSN 1668 - 8708 - Versión en Línea

E-mail: revistacientifica@fce.unam.edu.ar 


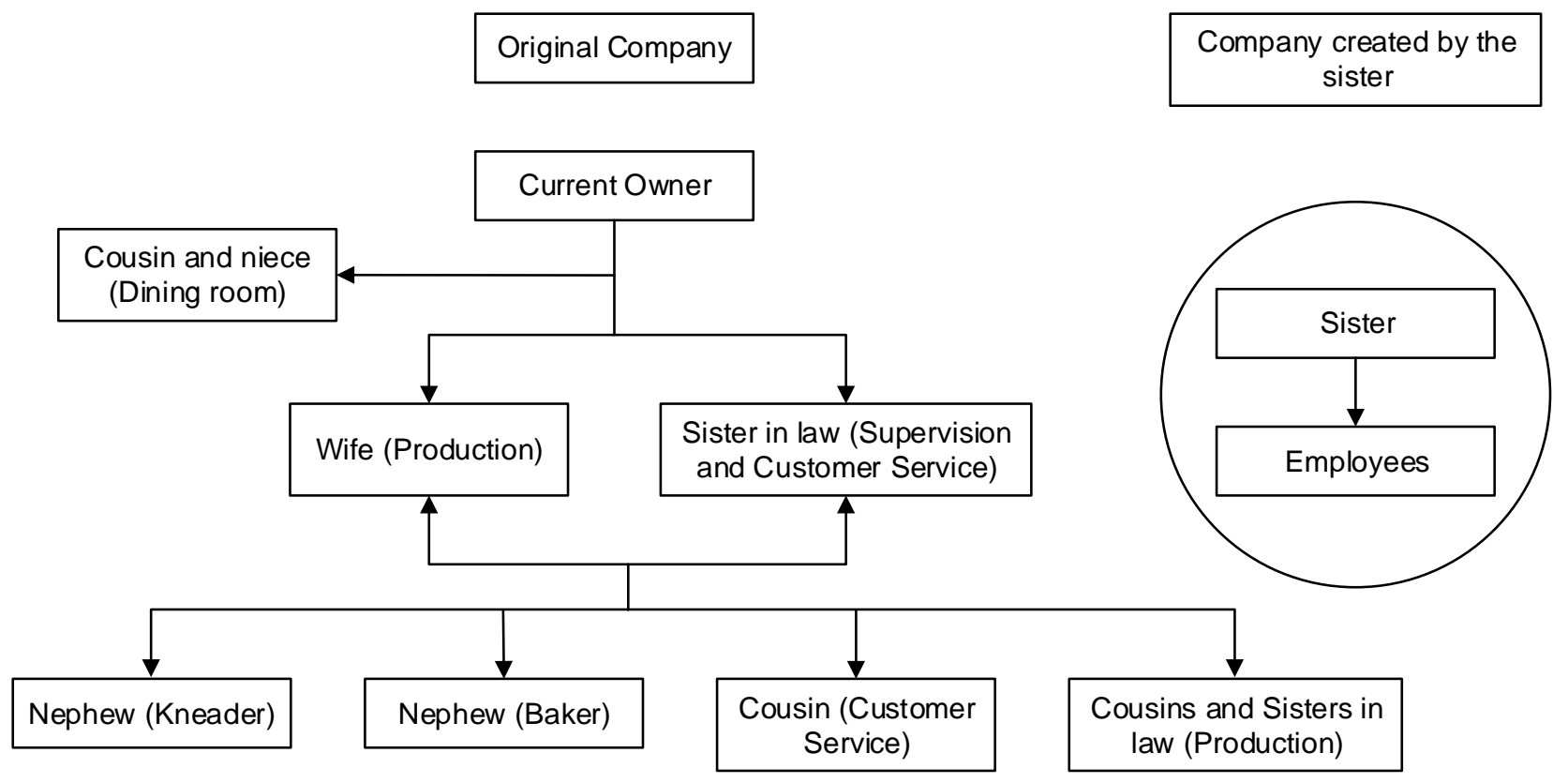

Figure $\mathrm{N}^{\circ}$ 2. Family contribution with the current owner in the company

Source: Own Elaboration

Of the studied dimensions in the investigation, taking the succession process as the main variable, each one of them is analyzed in terms of time, before and after the process, as shown in Table $\mathrm{N}^{\circ} 2$.

Table $\mathbf{N}^{\circ}$ 2. Company before and after the succession process

\begin{tabular}{|l|l|l|}
\hline \multirow{2}{*}{ Dimension } & \multicolumn{1}{|c|}{ Company } \\
\cline { 2 - 4 } Family & $\begin{array}{l}\text { Before succession } \\
\text { The founder, mother of the current } \\
\text { owner, was the most supportive person } \\
\text { for the family and was the decision maker } \\
\text { for the company. Before the succession, } \\
\text { only her opinion was respected since she } \\
\text { was the only one who could make } \\
\text { decisions. }\end{array}$ & $\begin{array}{l}\text { Before she passed, the founder left the } \\
\text { business in the hands of her eldest son. } \\
\text { Several informants mention that the } \\
\text { decision made was the best. }\end{array}$ \\
\hline Leadership & $\begin{array}{l}\text { Since its opening, the company used only } \\
\text { one type of leadership, which was the } \\
\text { autocratic; family had to respect the } \\
\text { decisions that were made. }\end{array}$ & $\begin{array}{l}\text { Nowadays, that has changed and the } \\
\text { leadership is situational, a type of } \\
\text { leadership characterized by being } \\
\text { changeable depending on the situation, } \\
\text { and thus being able to make the best } \\
\text { decision that according to the owner of } \\
\text { the company is always looking out for the } \\
\text { good of both the company and the } \\
\text { workers. }\end{array}$ \\
\hline Succession & $\begin{array}{l}\text { Previously, there was never a successor } \\
\text { plan, since the term was not known as }\end{array}$ & $\begin{array}{l}\text { The company has grown and has } \\
\text { become very competent within the }\end{array}$ \\
\hline
\end{tabular}

"Visión de Futuro" Año 16, Volumen No 23 N², Julio - Diciembre 2019 - Pág. 90 - 101 URL de la Revista: http://visiondefuturo.fce.unam.edu.ar/index.php/visiondefuturo/index

URL del Documento: http://visiondefuturo.fce.unam.edu.ar/index.php/visiondefuturo/issue/view/16

ISSN 1668 - 8708 - Versión en Línea

E-mail: revistacientifica@fce.unam.edu.ar 


\begin{tabular}{|c|c|c|}
\hline & $\begin{array}{l}\text { such; however, it was known who would } \\
\text { be the successor in charge of the } \\
\text { company for the second generation. }\end{array}$ & $\begin{array}{l}\text { market where it is located, and many } \\
\text { know that it is a successful FB. The } \\
\text { future of the succession for the third } \\
\text { generation is yet to be seen. }\end{array}$ \\
\hline Values & $\begin{array}{l}\text { In any company, it is important to have } \\
\text { qualities that make the company unique, } \\
\text { such as the values that govern it and why } \\
\text { it is characterized, like the way of working } \\
\text { or living inside and outside the company. } \\
\text { This, it is based on some interviewees, } \\
\text { where they mentioned that they have } \\
\text { always been characterized by teamwork, } \\
\text { strength and perseverance. }\end{array}$ & $\begin{array}{l}\text { With the time passing and the success } \\
\text { that the company has achieved with its } \\
\text { new owner, today they are still } \\
\text { characterized in the same way, } \\
\text { emphasizing that for them it is important } \\
\text { to stand and do things well, so having } \\
\text { humility respect and remain united has } \\
\text { always worked. }\end{array}$ \\
\hline $\begin{array}{l}\text { Company } \\
\text { (Property) }\end{array}$ & $\begin{array}{l}\text { The company was not seen as a } \\
\text { business by its founder, since she saw it } \\
\text { as a development to move her family } \\
\text { forward; her founder was passionate } \\
\text { about it. }\end{array}$ & $\begin{array}{l}\text { With the new owner, things began to } \\
\text { change and management became more } \\
\text { focused on business. Today, it continues } \\
\text { to be successful thanks to the products } \\
\text { that the founder left, and that her son has } \\
\text { managed to maintain as a legacy that } \\
\text { anyone can enjoy. }\end{array}$ \\
\hline
\end{tabular}

Source: Own Elaboration

\section{CONCLUSION}

The objective of this research was to identify the type of leadership exercised during the succession process in a Mexican family business, through various semi-structured interviews, which was achieved. In this sense, the main findings allow us to generate the following conclusions in three aspects. The first of them is that through the succession process, the direction of the business is transferred to a new person; however, the type of leadership is not generated by inheritance, succession or tradition. Each manager will manage the company according to their abilities, aptitudes and attitudes, in such a way that the founder did it in an autocrat way and the successor with certain flexibility depending on the situation.

After the succession process, the new top leader generates a reconfiguration in the organizational structure; on the one hand, by establishing a new relationship among the members of the company and the family; on the other hand, by incorporating into the business relatives with greater generational closeness and the nucleus.

With a great relation with the previous statement, the decision of the new successor is not accepted by all, which it originates familiar conflicts, manifested in the disagreement of one of the possible successors, generating the separation and the displeasure between them, which derives in the opening of a new competing company.

"Visión de Futuro" Año 16, Volumen No 23 No2, Julio - Diciembre 2019 - Pág. 90 - 101

URL de la Revista: http://visiondefuturo.fce.unam.edu.ar/index.php/visiondefuturo/index

URL del Documento: http://visiondefuturo.fce.unam.edu.ar/index.php/visiondefuturo/issue/view/16

ISSN 1668 - 8708 - Versión en Línea

E-mail: revistacientifica@fce.unam.edu.ar 
Therefore, the post-decision aspects and the exercise of leadership in relation to the performance of the company, the structure of the organization and family must be examined, as well as diminishing and avoiding conflicts that have consequences of business and/or family separation. One of the objectives of this type of companies is that it is precisely the family that remains the owner in the following generations, providing benefits both for the family and for society in general, thus favoring its continuity and permanence.

\section{REFERENCES}

Please refer to articles in Spanish Bibliography.

\section{BIBLIOGRAPHCIAL ABSTRACT}

Please refer to articles Spanish Biographical abstract. 